Volume 4, No. 3, September - December 2019 ISSN: 2503-4235 (p); 2503-4243 (e)

Shirkah

Journal of Economics and Business 


\section{Shirkah}

Journal of Economics and Business

Vol. 4, No. 3, September-December 2019

ISSN: 2503-4235 (p); 2503-4243 (e)

\section{Editor in Chief}

Fitri Wulandari

\section{Managing Editor}

Jasanta Peranginangin

\section{Editorial Boards}

Abdul Azim Islahi

Islamic Economics Institute, King Abdulaziz University, Saudi Arabia

Abu Umar Faruq Ahmad,

UBD School of Business and Economics Universiti, Brunei Darussalam

Cedomir Nestorovic,

ESSEC Business School Asia Pacific, Singapore

Johan Fischer,

Department of Social Sciences and Business Roskilde Universitetscenter, Denmark Muhamed Zulkhibri,

Islamic Research and Training Institute, Islamic Development Bank, Saudi Arabia M. Kabir Hassan,

Department of Economics and Finance, University of New Orleans, United States Musa Asy'arie,

Faculty of Islamic Economics and Business, IAIN Surakarta, Indonesia

Nunung Nurul Hidayah,

Aston Business School, Aston University, Birmingham, United Kingdom

Saim Kayadibi,

Department of Economics, Kulliyyah of Economics and Management Science,

International Islamic University Malaysia, Malaysia

Shaikh M Ghazanfar,

Departement of Economics, University of Idaho, Russian Federation

Sigit $\mathrm{S}$. Wibowo, 
Department of Management, Faculty of Economics and Business, Universitas Indonesia, Indonesia

Vihang R. Errunza,

Desmarais Global Finance Research Centre, Desautels Faculty and Management, McGill University, Canada

\section{Assistant to Editor \\ M. Endy Saputro \\ M. Zainal Anwar}

Shirkah Journal of Economics and Business is a peer-reviewed journal published three times a year (January-April, May-August and September-December) by Faculty of Islamic Economics and Business, Institut Agama Islam Negeri (IAIN) Surakarta Central Java, Indonesia. The main objective of Shirkah is to offer an academic space of exchange ideas and initiate the increase number of qualified article produced by postgraduate students, practitioners and academicians.

\section{Editorial Office}

Ruang Jurnal Shirkah

Lantai Dasar, Sayap Barat, Fakultas Ekonomi dan Bisnis Islam, IAIN Surakarta

Jln. Pandawa No. 1, Kartasura, Sukoharjo, Jawa Tengah Kode Pos. 57168

Phone (+62271) 781516 Fax: (+62271)782336

E-mail: shirkahjournal@iainsurakarta.ac.id; shirkahiainsurakarta@gmail.com

Website: http://shirkah.or.id/ 


\section{Shirkah}

Journal of Economics and Business

Vol. 3, No. 3, September-December 2018

ISSN: 2503-4235 (p); 2503-4243 (e)

\section{Table of Contents}

\section{Articles}

M. Falikul Isbah

External Influences and Supports to Pesantren's Socio-Economic

Activism in Changing Context

R. Lukman Fauroni

The Economic Community of Pesantren Al-Ittifaq Opposing

Market Capitalism and the Improvement of Competitiveness

M. Musa Al Hasyim

403

Creative Industry Development in Pesantren Tebuireng

Kuat Ismanto

N. Nasrullah

429

Multiplier Effects of Pesantren Walindo

Mustaghfiroh Rahayu

455

Social Embeddedness and Economic Behaviour in Pesantren Mlangi

Helmi Haris

Muhammad Nashirudin

481

Lombok as an Indonesian Halal Travel Destination 


\title{
Multiplier Effects of Pesantren Walindo
}

\author{
Kuat Ismanto \\ Faculty of Islamic Economy and Business IAIN Pekalongan \\ kuatismanto79@gmail.com \\ M. Nasrullah \\ Faculty of Islamic Economy and Business IAIN Pekalongan \\ kuatismanto79@gmail.com
}

\begin{abstract}
This study aims to investigate the multiplier effects of business run by pesantren in economic, education, and social fields. It is a field research conducted in Pesantren Walindo, Siwalan district, Pekalongan. By using qualitative approach, the data were collected through observation, interview, and documentation. The presence of the researcher was the key point in obtaining the data. The deep interview was conducted to some related parties, such as kyai, managers, and santri (students). This study reveals several findings. First, there is significant effect of developing business in Pesantren Walindo on its development and independence because it can cover $60 \%$ of operational funding without drawing fee from the santri. Second, related to the business units development, this pesantren is able to strengthen the sense of entrepreneurship in santri's spirit. The business unit management run by the santri along with kyai and nyai build their business awareness which can be their foundation after they graduate from this pesantren. Third, regarding the social filed, the relationship between the pesantren and the society are conducted both in the form of partnership and other kinds of relationship which bears the sense of belonging of the society toward the pesantren and their trustworthy to register their children there.
\end{abstract}

Keywords: pesantren, multiplier effects, pesantren business units

\section{Introduction}

Pesantren (Islamic boarding schools) are Islamic educational institutions that have been established for a long time. At first, they were 
used as a center of religious education and Islam spread (Nuha, 2016). Pesantren are the educational institutions applying norms, values and rules that can change person's character to have more environmental care, be more cooperative and have capability in solving problems in the environment (Fatimatuzzahroh, Abdoellah, \& Sunardi, 2015). Nowadays, pesantren are expected to be more than carrying out their traditional functions, which are "transmitting and transferring Islamic sciences, maintening Islamic traditions, and reproducing scholars". They are demanded to be the health education center, technology development for rural communities' center, saving and preserving the environment center, and the most important function is being the center of economy empowerment of the neighborhood (Azra, 1997). These institutions are also places to build santri's independence, to decrease their dependency on others (Sanusi, 2012).

Some of the pesantren have tried several efforts of economy empowerment in various concepts, including: (1) economic business regarding kyai as the most responsible figure in developing pesantren, (2) economic business for strengthening the operational costs of pesantren, and (3) economic business for santri by educating them several useful skills and abilities for their life after leaving the pesantren (Nadzir, 2015). Some pesantren which have developed the economic concepts above are Pesantren Sidogiri in East Java, Pesantren Tazakka in Batang and Pesantren Al Hikmah in Tegal, Central Java (Nasrullah, Ismanto, \& Nalim, 2018). The pesantren's economic or business management have been implemented both in traditional (not categorized as a good management) and modern ways (Hamzah, 2015). The successful economic development of the pesantren can be determined by the transformational leadership factor of a kyai (cleric), as KH. Abdul Ghofur has done in Pesantren Sunan Drajat Lamongan in East Java (Indrawati, 2014). 
According to the survey conducted by the central bank, the majority of Pesantren's funding comes from santri's contributions while the contribution of the business units is only about 12 percent. In addition, the government also supports the large amount of pesantren's funding. The small contribution of the business units is caused by several obstacles in the economic development faced by the pesantren, including marketing, networking, capability, and capital problems (Kompas.com, July 20,2018). The ones that have developed this business is categorized as creative pesantren. Development of the creative economy in the pesantren inspires santri to have sense of entrepreneurship (Nofiyanti, 2017). The social business developed by Pesantren Sidogiri has provided a real financial contribution to the operational cost of the pesantren. In addition, it has also provided entrepreneurship education for its santri (Reginald \& Mawardi, 2015). There are several reasons for the institution to establish the business units. One of them is the need of the pesantren itself to survive and earn for living (Suwito, 2008). The results of the pesantren business units can be used for paying the operational costs, developing pesantren and increasing the santri's welfare (Hamzah, 2015). Pesantren Sidogiri in East Java develops business units (financial departments) as the result of its concern on the environment (Setiawan \& Nimran, 2013).

Walindo is one of the pesantren in the Pekalongan region, Central Java which has developed those kinds of business. This pesantren claims that the main purpose of establishing the business units is not to earn a living but to protect the santri from consuming too much snacks from outside the pesantren. This is based on the commitment of the Kyai stating that the pesantren do not demand syahriah (tuition fee) from the santri . He believes that Allah provides sustenance for the pesantren's management from anyways. In its development, the results of the pesantren business unit have been able to contribute to the operational costs and development. 
The pesantren business unit does not only contribute economically to the institution itself, but also build the santris independence and entrepreneurship. Educational institutions can create entrepreneurs if they have capability in developing the entrepreneur culture in that environment. Culture building can be shaped by involving students in business units in the educational institution (Hamid, 2012). More specifically, Fatchan, Amirudin, \& Soekamto (2015) stated that Bandongan system (agribusiness development) developed by pesantren is possible to form norms, ethics and honesty in santri's characters as they act based on what they learn in kitab kuning (the yellow book). Pesantren Walindo uses 'impoverishment' method for all santri from the beginning they enrolled the pesantren in order to shape their independence and resilience to survive in living their lives. Furthermore, this pesantren also encourages the santri to get involved in managing the business units. This involvement brings a positive impact on them, that they learn patience, perseverance and honesty which are the important values for achieving success. This system has got success in creating new entrepreneurs, and it was proven by several alumni who have successfully run various businesses.

According to the elaboration above, this study analyzes the development of business units in pesantren. It also analyzes the extent to which the business units are able to contribute in the pesantren's development. By using a multiplier effect theory, it measures to what extent the business units are able to grow up the new businesses in the pesantren neighborhood. A multiplier effect is an activity that can spur the emergence of other activities. Referring to the concept developed by Frechtling (1994), Tarigan (2002), Moretti (2010) and Domanski \& Gwosdz (2010), the multiplier effect in developing local economy is an impact caused by activities in certain fields that it is able to mobilize activities in other fields. 
The use of the multiplier effect theory in various studies seems to be potential to describe a condition in appropriate way. Al Arif (2012) applied this theory in zakat (alms) and waqf (endowment), Lestari (2015) applied it in oil palm plantation, Santosa (2011) applied it in tourism, and Sondakh \& Pakasi (2017) applied it in agribusiness. Besides, this paper is reviewed by using this effect multiplier theory. This study chooses pesantren Walindo located on the northern coast of Pekalongan Regency because of several reasons. Firstly, this pesantren has several business units whose results are for funding itself. Secondly, santri are free of tuition fee for their education. Thirdly, there is a cooperation between the pesantren and the society, which provides mutualism relationship for both of them. Therefore, this article discusses the development and management of business units in pesantren Walindo. In addition, it discusses the impact of the pesantren business units viewed by the effect multiplier theory.

This research is categorized as a field research by using qualitative approach which chooses pesantren Walindo as the object of the study (case study). This study focuses on the multiplier effect of business ventures developed by the pesantren toward the environment. It used the concept of the multiplier effect developed by Frechtling (1994) and Domanski \& Gwosdz (2010). The multiplier effect in local economic development is impacts caused by activities in certain fields, both positive and negative. It empowers activities in other fields because of the direct and indirect linkages which ultimately encourages the development of several activities. Primary data is obtained directly through three ways, namely observation, interviews, and documentation. Interviews were conducted with the pesantren leaders, pesantren managers, business unit managers, and santri. The data are analyzed using "content analysis". 


\section{Pesantren Walindo}

Pesantren Walindo is an Islamic educational institution that adheres to salafyyah tradition (opposite from modern tradition). This pesantren is located on Gusdur Street No. 1, Boyo Teluk Village, Siwalan District, Pekalongan Regency. It was established in 2002, incorporated as a foundation and has had NSPP (510333260018). This boarding school is led by KH. M. Al Fardani. It has an approximately two hectares area with 6000 square meters of building area and its value is about ten billion rupiah. The building consists of boarding houses (male and female), schools, mosques, meeting rooms, business units and others. The land and buildings occupied for boarding schools are not the private property, but they are owned by the foundation.

Pesantren Walindo has 620 PDF students and 20 tahfidz students. Those students are taught by 36 Ustadz and ustadzah (teacher), who $25 \%$ of them graduated from S1 degree and the rest are alumni of some pesantren from various regions in Java. However, to meet the teaching criteria, this institution keeps encouraging and facilitating the teachers to continue their studies. Kyai Fardani, the leader of the pesantren Walindo, has had a commitment to run this pesantren since it established without charging a single fee to the santri. This is in accordance with what was ordered by his teacher. Although the santri do not pay for the tuition fee, he provides a dormitory and serving meal twice a day for free as the facilities for them. Most of Walindo's santri are from the middle to lower economy levels. Nevertheless, there are also santri coming from the middle to upper economy levels.

The concept of education, especially economic education instilled by the Kyai is carried out in several ways, namely impoverishing santri, having togetherness, and the kyai as the role model for the santri. The method of impoverishing santri is carried out by implementing the 
principle that all santri must be impoverished. There is no different treatment between santri coming from upper to middle and middle to lower levels. Even santri from upper middle levels experience more severe punishments, including: sleeping on cardboard boxes, cleaning the sewers every morning, and so on. This principle aims to teach the santri in understanding and appreciating life. With this approach, santri are also expected to become strong individuals in facing life challenges and earning a living. The concept of togetherness is the second way carried out by the pesantren. The pesantren's leader always says that Walindo does not belong to Kyai Fardani, but santri and the society. In every routine teaching followed by santri, the Kyai always reminds them that in earning a living, humans are required not only to pray but also to try. When humans get success, they must not be selfish, since all the earnings come from Allah.

The third concept conducted by this pesantren is entrusting the kyai and family as the role models. The Kyai and Bu Nyai (kyai's wife) always show examples to their santri to survive. This is clearly appeared from their ideas in building business units, one of which is to help the operational costs of the pesantren. Moreover, they instill honesty, hard work and they do not recognize pesantren assets as their private assets and this principle is also instilled in their children. They stated that if their sons and daughters do not contribute anything to Walindo, the better way for them is living outside Walindo. Another example is when the Kyai family takes goods from the business units and they have not paid for it, they must be billed to pay. The best practices carried out by the Kyai family is very impressive for the santri.

The pesantren also involves and entrusts santri in managing the business units. Each business unit has a person in charge. This management is more effective in fostering the spirit of santri entrepreneurship as well as learning management and accounting on their own. The concepts above 
are applied by the pesantren in order to create successful santri generation in the world and the hereafter. To meet the santri's needs, pesantren have three sources of funding. The first source comes from the government and the society. The second source is from pesantren business units and the third source cannot be explained rationally. The kyai stated that santri brought their own blessings. Often the amount of funds and sources are more than their expectation (min haisu la yahtasib). The operational costs for pesantren supported by the society are in the various forms. For example, the Deputy of the Regent donated 5 quintals of rice. The society contribution is in the form of santri's boarding house construction. The santri family present rice and or amount of money to the kyai (clerics). When Pak kyai preaches (lectures) and obtains bisyaroh (amount of money representing gratitude), it will be included as pesantren income which can be used as pesantren's operational costs.

Another source of operational costs of Pesantren Walindo is the existence of the pesantren business units. The existing business units contribute $60 \%$ in meeting the operational needs. Although the business units contribute significantly to the pesantren's needs, the main reason of establishing the business units were not to meet operational funding needs, but to prevent the santri from buying too much snacks outside the pesantren. The condition is in line with the findings by Abdullah \& Hoetoro (2011), which mentioned the main purpose of Muslim entrepreneurs is establishing a business not solely for financial need, but the more important purpose is to realize a meaningful value in accordance with the teachings of Qur'an and Hadith. As a manifestation of developing pesantren's role, there are many pesantren have also established business institutions. Generally, a business unit is established to get profit.

According to Bu Nyais statements, before the business units established, many santri had had to go outside the pesantren to meet their 
daily needs, snacks or food. Pesantren's leader concerns to this situation and he assumes that santri can receive the negative effects when they come outside of the pesantren. The effects can be illness (due to uncontrolled food), smoking (male santri) and operating mobile phone outside the pesantren. However, there is a positive side of this condition. It provides income for the surrounding society. They get profit from the santri who buy their need outside of the pesantren. Based on the concerns above, the pesantren initiated to establish business units. Since 2012, the pesantren has begun pioneering several business units. These business units are located around the pesantren. At first, the establishment of the business units received a negative response from the society caused by their decreasing income. In the end, the society understood this condition. Precisely the recent conditions are different, good cooperation can be established between the two parties.

The three funding sources obtained by the pesantren are used for its operational costs. The biggest need is to pay the salaries for the teachers (ustadz/ustadzah) and to serve meal for the santri. In this pesantren, santri are not charged a monthly fee (shahriyah), but they live in a boarding house and enjoy free meals twice a day (morning and evening). To provide meals for santri, 1 quintal of rice is needed every day. In order to pay salaries for the teachers and provide all of the santri's needs for a month, this pesantren needs is Rp. 50,000,000. Regarding the existence of the Walindo which has changed so far, in line with Nur Syam's opinion (2017), it has transformed into a center for community empowerment since 1980 and later in the 2000s it became the center of populist economic development. This dynamic occurred as the result of pesantren's ability in forging good relationship with the surrounding environment (Qomar, 2002). 


\section{Business Units}

There are a number of business units that have been run by Walindo boarding schools. They are Santriqua, Santrihijab, Santrimart, Berbaur cell, calendar printing, marawis and marching band, cows trading (specifically Eid al-Adha), laundry business. The very first capital of each business unit comes from the pesantren leader. If the business runs well, the pesantren's financial management can be separated from the leader's financial management. Because there is no entrepreneurship education included in the pesantren curriculum, the leader only show examples of running the business. Therefore, the leader tend to conducting tausiyah (preaching) and the role model strategies to educate the santri.

Business units run by Pesantren Walindo can be described in the following details:

\section{1) Santriqua}

The mineral water business 'Santriqua' produces RO Hexagonal mineral water. The product for processing the mineral water are produced by the pesantren themselves namely "Santriqua Berbaur." This bottled mineral water has obtained legal permission from the health department that it is safe to consume. Santriqua products are available in various sizes: small glasses, medium glasses, small bottles and medium bottles. This product are promoted in Pekalongan and surrounding areas.

The sales system relies more on consumers' orders. This pesantren does not commercialize this product that it is not sold or deposited at stores even though this product already has the permission. The sales system by relying on customers' orders becomes an obstacle for this business to maximize it profit. The customers' order is applied based on the consideration of the limited production capacity. The sales of Santriqua products usually increase when it is closed to Eid al-Fitr, during the 
celebration days and celebrations of religious days, such as the birthday of the Prophet SAW, Isra 'Mi'raj, and the Islamic New Year. To get closer to consumers, Santriqua's business provides delivery order by calling 0821349729xx. Ordering and shipping services are carried out by santri. Money turnover of this business is 25 million per month. This unit is able to obtain profits of around Rp. 7 million to Rp. 8 million per month.

2) Santrimart

Santrimart is a business unit of the pesantren that provides santris various daily needs, such as: basic needs, food, drinks, stationery, gallons of mineral water, clothing, household appliances, toiletries, and various accessories. The stock delivered by the marketers who offer their products directly to the pesantren. Apart from the marketers, some of the goods are bought in Wiradesa Pekalongan market. The goods management is carried out by the santri appointed by Bu Nyai while the financial administration and management is carried out by the santri and supervised by Bu Nyai. Although the practice of financial administration and management still uses traditional way, the accounting principles have been applied, by separating financial assets of the santrimart from Bu Nyais finances. Even every item she took from Santrimart would be recorded and billed if it had not been paid. The main consumers of this business are santri and santri's parents who visit their children. Santrimart's income increase significantly by the time there is an event held by the pesantren. The money turnover of this business is approximately 50 million rupiah per month. This business unit gains profit of around Rp. 7 million to Rp. 8 million per month.

3) Berbaur Cell

Berbaur Cell business is located next to Santrimart. The establishment of this business was motivated by a ban of bringing cellular phones (cellphones) in the pesantren which was intended to santri. The 
ban aimed to keep their focus on studying as well as avoiding the negative effects of cellphone. Berbaur Cell is a business unit provided by the pesantren to facilitate santri who want to communicate with their relatives and families. This business is not a business of buying and selling credit as in general, but providing service for santri who want to communicate using a pesantren's mobile phone. They must pay this service according to the amount of credit they have used. Berbaur cell provides a various operators so they are able to choose the operator based on their destination number. This business income is approximately $\mathrm{Rp} 2.5$ million per month. The profits are fully for the pesantren.

4) Santri Hijab

Unlike the other business units, Santri hijab is new in this pesantren. The uniqueness of this business unit lies in the items provided. In general, the word 'Hijab' is synonymous with clothing for Muslim women. However, the items sold in this business unit consist of various kinds of products, such as: Muslim (man and woman) clothes, uniforms, sarongs, veils, muslim dress, caps, sleeping equipment, frames and other accessories. Several products such as sarongs, Muslim (man and woman) clothes, veils, muslim dress, caps, bought in wholesale shops / markets and theirs manufacturers. This pesantren cooperates with society to get uniforms for this unit. Besides purchasing the products from shops and markets, there are also people who leave their products (fashion) in santri hijab.

Walindo produces sleeping equipment, such as mattresses, pillows and bolsters because this pesantren believes that providing the sleeping equipment for the santri is very important. The pesantren only provides simple rooms and bedding. Therefore, if santri need sleeping equipment, the pesantren provides it in Santri hijab. The process of making mattresses, 
pillows and bolsters is done by the santri. The Santri hijab consumers are santri and guests visiting the pesantren. The management of this business unit is the same as the santrimart's. Even though Santrihijab is a new business unit, the income reaches around Rp. 3-4 million per month.

5) Calendar

Calendar is one of the indirect promoting tools owned by Walindo. Calendar becomes a promoting tool because it shows the profile of this pesantren as well as the activities and achievements. Bu Nyai stated that many santri's family knew Pesantren Walindo from purchasing the calendars before. The calendar can be categorized as a seasonal business because the process of designing and printing is only based on the year that will run. After being produced, the calendar is promoted by the santri in Pekalongan region and its surroundings. The promotion uses a dropping system for each region. Some groups of santri were dropped to some regions (sub-districts or villages) and they offer the calendar using door to door method. Although the cost of each calendar is about Rp. 25 rupiah, sometimes he buyers give more money or buy more than 1 calendar since they want to participate and support the pesantren.

The profits resulted from the calendars are not large enough but it provides tremendous benefits for the pesantren. People know more about Walindo and some of them register their children to be santri in this pesantren. Moreover, some of the people are eager to donate their own for the pesantren. The profits of selling the calendar for each period is around $\mathrm{Rp} 5$ million and the assets of this business are around Rp100 million.

6) Cows Trading

This business can be said as an accidental effort to form because this business is the result of the wide network and the trust of the people who tend to buy sacrificial animals through pesantren. People trust the 
pesantren due to the fact that it is considered as the party who knows more about the qualification of sacrificial animals. On the basis of these beliefs, every time before Eid al-Adha this business is carried out. This business is a seasonal business because it is carried out only at the time of Eid al-Adha. This business is only buying and selling cows, and it excludes farming. The pesantren brings the cows owned by some partners outside the city and resells them by regarding what the people ordered. Although this business is carried out by Pak Kyai, it is not claimed as a personal business, because the results would be used for the pesantren. Despite being a seasonal business, the results of this buying and selling are quite good. This business can be run so far because of the wide partnership of the pesantren leaders. Every Eid al-Adha this pesantren is able to obtain about Rp 20 million.

7) Marawis and Marching Band

This business is an art business unit in the form of singing sholawat (Islamic song) and marching groups. The members of this group are the santri. They are trained periodically by trainers coming from internal and external pesantren. In the beginning of its establishment, this unit was only formed to participate in the event held by the pesantren and join the competition among schools. Over time, the group is invited by the surrounding society. It is categorized as a business unit as it provides income for the pesantren. As part of the business unit, marawis and marching band do not pursue profits. It was proven by the commitment of this unit not to set a certain cost for their performance. Kyai only advises the inviter to care about the members of the group. Marching group is likely invited by TPQ, Madin, and several ceremonies. Whereas the marawis group is usually invited to participate in any religious celebrations and special events held by the society. They are not only invited from within but also from outside the city. This art business promotes income in about Rp. 40 million per year for the pesantren. 
8) The Pesantren Canteen

The pesantren canteen was established to meet the daily consumption needed (food, drink and snack) by the santri. This pesantren provides canteen that is located inside the pesantren to ease the santri in having meals. Alike the other business units, this business was also established by the pesantren's manager and managed by the santri. There are food and side dishes (fried foods and others) are cooked and sold in this canteen by the santri. This unit provides an opportunity for the surrounding society to leave snacks in the canteen with a profit sharing system. However, Walindo applies rules regarding the deposited snacks. The snacks must be hygienic, halal and healthy since it does not want the santri getting sick because of unhygienic food. The profit of the canteen business unit is around Rp 2.5 to Rp 3 million every month. All profits obtained are used to support the pesantren's operational cost.

9) Laundry Business

Laundry business was established in 2018 which aimed to serve santri who did not want to wash their own clothes. This effort was inspired by several events experienced by the santri. Some of their clothes were exchanged or even lost as they forgot to lift the clothes from the clothesline. This business is proposed to facilitate the santri in avoiding the similar incidents.

The cost of this laundry is Rp.4500 for each kilogram. Bu Nyai stated that this cost is only the amount of money to pay for soap and electricity. Almost all of the business units owned by Walindo are basically providing facilities without prioritizing profit. Since this business is still relatively new, the profits are only around Rp 1.5 million per month. Besides the business units above, the leader also run other businesses such as Albasia plantations located in Pekalongan Regency area, and vegetable 
plantation. Albasia plantations are managed by Pak Kyai and the results appear after 5 years. This plantation has been harvested once and some parts of the results are partly used to support the operational cost of the pesantren. The vegetable plantation is in Wonosobo which the results are not for sale, but for fulfilling the needs of side dishes.

Business units run by this pesantren were initiated by Pak Kyai. However, Bu Nyai has an important role in managing those businesses. Practically, each business unit is led by santri as managers who are appointed to manage and report the results to Bu Nyai. The senior santri were appointed to be managers. This appointment was done informally by considering the santri's seniority and character. For santri who actively manage the business, they receive basic salary. Alumni receive salary which the amount is determined by the management. The managers of Santrimart and Santriqua receive a holiday allowance on Eid al-Fitr. Bu Nyai as the 'main manager' of the pesantren business units always emphasizes that the businesses run by the pesantren are not family owned but they belong to the pesantren. As the consequence, all financial circulation of the business units is separated from the leader's finances. Even though the system is still manual, every business unit is required to have a presentable bookkeeping. In general, the business units run by this pesantren do not experience any significant obstacles during their operations. Some of the obstacles faced by the pesantren are (1) the regeneration of business unit managers. Most of the santri whom Bu Nyai appoints as business unit managers do not want to be managers forever, especially after they graduate from the pesantren. Therefore, Bu Nyai has to look for other santri and treat them from the beginning in managing the business. (2) the use of a manual bookkeeping system sometimes produces imbalanced record. The manual bookkeeping is not caused by their disability in buying the supporting equipment, but the human resource managers are not familiar with the 
computerized systems and applications. (3) one of the sales systems carried out by pesantren business units is door to door (calendar sales). The door to door sales system requires heavy costs and energy. The santri told that frequently they were underestimated by people even some of the people refused their presence as they disturbed them. Even so, the santri claimed they can learn something based on the displeasing event.

\section{Economic Multiplier}

The business units run by Walindo has economic multiplier. It can be seen from the santris daily need, which can create business opportunity to fulfill their daily need. The high level of food and side dishes demand provides opportunity for the rice sellers and farmers to meet the pesantren's need. Santris daily needs involving meals, beverages and snacks have been able to create the pesantren's canteen serving various food, beverages, and snacks. The canteen managers have a cooperation with tempe (soybean cake), tahu (tofu) and vegetables business to fulfill the canteen stock. Some of the snacks sold in the canteen are from the society, that it provides job opportunity for the society.

Another business, Santrihijab, selling various Muslim wears and uniform as the result from the cooperation with the society can increase the society's income. One of the benefits of this business is supporting the pesantren's operational cost (salary for the teachers). The business unit must contribute the salary for the teachers. The teachers receive their salary on time for they can fulfill their family need. The income of each unit in this pesantren is about Rp 30 million per month. By comparing the total of operational cost which reaches $\mathrm{Rp} 50$ million per month, these units are able to contribute $60 \%$ of the total cost. 


\section{Educational Multiplier}

The business units run by this pesantren which are categorized as educational multiplier involve the santris involvement in managing the busniness units. The involvement aims to build entrepreneurship and honesty spirit in the santris character in running the business. Although the entrepreneurship is not included in the pesantren's curriculum, the best practice method inspires them. This is in line with their statement: they choose Bu Nyai as the role model. They argue that she is a successful woman in taking care her family and business.

The santri's experience in selling calendar provides them some values which cannot be gained directly in the pesantren's curriculum. They build their interaction with the different characters of people in society that they recognize humans have different characters of each other. Sometimes they are well treated by the simple or lower class. On the contrary, sometimes they get unpleasant response from the upper-class society. They recognize that for earning a living, they have to work hard. Some of the alumni who were the managers of these business units have built their own business. However, They do not forget their pesantren and they build the network and relationship to support the institution.

\section{Social Multiplier}

The existence of Walindo changes the social structure of its neighborhood. Before its establishment, most of the society nearby had shallow understanding in religious practices, even some of them are non-muslim. After this pesantren was established, they have deeper understanding in religious practices and some of the non-Muslim have converted into Islam. At first, this pesantren's business was blocked by the society since they ascribed the business can reduce their income. In 
addition, they assumed that the pesantren wanted to get its own profits. In fact, the purposes of establishing the business is to avoid the bad effects coming from outside the pesantren. Finally, by using an appropriate approach, the society are eager to accept the pesantren's businesses.

Some of the pesantren's business units such as Santriqua, calendar, and marching band/marawis give positive effects for the society. For an instance, the society expect the new calendar sold by the pesantren, to not only buying the calendar but also supporting the financial need for the pesantren as a part of social mission. The existence of the calendar as the promotion tool has motivated some parents to enroll their children into this pesantren. Absolutely this is a positive choice among the other parents' choices which focus only on the academic education. In general, the existence of the business units build the sense of belonging toward the pesantren. Therefore, their social character rises and it enables them to contribute in developing the pesantren.

\section{Conclusion}

According to the elaboration above, this paper draws several conclusions. First, the developing stage of the pesantren business units are initiated by the pesantren's leader. The best practice applied by the leader is a role model for the santri in managing business. Second, the existence of the business units provides significant effects on the pesantren's development and independence. Third, the developing business units brings out three aspects of multiplier effect, including economic, educational and social aspects. In educational field, the business units are able to strengthen the development of the sense of entrepreneurship among the santri. In economic aspect, the effects of the business development clearly appear in the relationship pattern of the pesantren and the society, involving partnership and other patterns. The society are the suppliers of the products 
used by the santri. In social field, this pesantren is not only an educational institution, but also the society partner in any religious and social affair.

Business activities run by this pesantren have back and forth relationship related to the pesantren development. They emerge some suggestions to support the development. First, the pesantren should provide operational and financial education for santri, who are involved in the business management, especially entrepreneurship, through curriculum change. Second, the government should support the pesantren development, both for financial and non-financial need. Therefore, this pesantren is able to be financially independent in facing this globalization era. Third, the pesantren should have developed businesses that are accessible for the society. 


\section{References}

Adullah, M. A., \& Hoetoro, A. (2011). Social Entrepreneurship as an Instrument to Empowering Small and Medium Enterprises: An Islamic Perspective. International Journal of Management and Business Research, 1(1), 35-46.

Al Arif, M. N. R. (2012). Efek Multiplier Zakat Terhadap Pendapatan di Provinsi DKI Jakarta. Al-Iqtishad: Jurnal Ilmu Ekonomi Syariah, 4(1). Al Arif, M. N. R. (2012). The Cash Waqf Multiplier Effect and The Influence to Poverty Alleviation Program.

Asiyah, U., \& Prasetyo, R. A. (2017). The Role of Islamic Boarding School as Socialization Agent of Ecological Values (A Case Study in Salaf -Modern Islamic Boarding School ), 20(4), 9凶17.

Asnawi, Y. H., \& Soetarto, E. (2016). Catabolism of Space and utilization of community as A Survival Strategy of Pesantren. Sodality: Jurnal Sosiologi Pedesaan, 4(1).

Asnawi, Y. H., Soetarto, E., Damanhuri, D. S., \& Sunito, S. (2016). Catabolism of Space and utilization of community as A Survival Strategy of Pesantren. Sodality: Jurnal Sosiologi Pedesaan, April, 83区91. Asrohah, H. (1999). Sejarah Pendidikan Islam. Jakarta: Logos Wacana Ilmu.

Azra, A. (1997). Pesantren: Kontinuitas dan Perubahan. sebagai 'Kata Pengantar' dalam Madjid, Nurcholish.

Basri, H. H. (2017). Model Pengembangan Ekonomi Pondok Pesantren: Studi Kasus Yayasan Pesantren Tiga Dimensi Pangkep Sulawesi Selatan. EDUKASI: Jurnal Penelitian Pendidikan Agama dan Keagamaan, 5(4).

Boulding, K. E., \& Economics, B. (1970). Essay On Society, Relegion ana Ethics, The University of Michigan. Ann Arbor.

Bustomi, I., Umam, K., \& Syari, F. (2017). Wirausaha lantabur kota cirebon. Al-Mustashfa: Jurnal Penelitian Hukum Ekonomi Islam, 2(1), 80囚90. 
Daulay, H. P. (2007). Sejarah Pertumbuhan dan Pembaruan Pendidikan Islam di Indonesia. Kencana Prenada Media Group.

Faozan, A. (2006). Pondok Pesantren dan Pemberdayaan Ekonomi. Jurnal Ibda, 4(1), 88-102.

Fatimatuzzahroh, F., Abdoellah, O. S., \& Sunardi, S. (2015). The Potential of Pesantren In Sustainable Rural Development. Jurnal Ilmiah Peuradeun, 3(2), 257-278.

Ghazali, M. B. (2001). Pendidikan Pesantren Berwawasan Lingkungan: Kasus Pondok Pesantren An-Nuqayah, Guluk-Guluk, Sumenep, Madura. Pedoman Ilmu Jaya.

Hamid, A. (2012). Pemilihan Kode Masyarakat Pesantren di Pesantren al-Aziz Banjarpatoman Dampit. SKRIPSI Jurusan Sastra IndonesiaFakultas Sastra UM.

Hamzah, S. N. A. (2015). Manajemen pondok pesantren dalam mengembangkan kewirausahaan berbasis agrobisnis: Studi multi-kasus di Pondok Pesantren Mukmin Mandiri Sidoarjo dan Pondok Pesantren Nurul Karomah Pamekasan Madura (Doctoral dissertation, Universitas Islam Negeri Maulana Malik Ibrahim).

Hariyanto, R. (2017). Menumbuhkan Semangat Wirausaha Menuju Kemandirian Ekonomi Umat Berbasis Pesantren (Studi Kasus Di PP Darul Ulum Banyuanyar Pamekasan). NUANSA: Jurnal Penelitian Ilmu Sosial dan Keagamaan Islam, 14(1), 185-212.

Huberman, M., \& Miles, M. B. (2002). The qualitative researcher's companion. Sage.

Jamaluddin, M. (2012). Metamorfosis Pesantren di Era Globalisasi. KARSA, 20(1).

Kutsiyah, F., Mustadjab, M., Anindita, R., \& Yustika, A. E. (2016). Analisis kinerja program bantuan pinjaman langsung masyarakat melalui lembaga pesantren di Madura. Jurnal Agro Ekonomi, 27(2), 109-134. 
Lestari, A. (2015). Analisis Multiplier Effect Ekonomi Perkebunan Kelapa Sawit di Kabupaten Mesuji (Doctoral Dissertation, Fakultas Ekonomi dan Bisnis). digilib.unila.ac.id.

Mahfudh, M. S. (2003). Dialog dengan Kiai Sahal Mahfudh: solusi problematika umat. Diterbitkan bersama Penerbit Ampel Suci [dengan] Lajnah Ta'lif wan Nasyr (LTN), NU Jawa Timur.

Mantra, I. B. (2004). Filsafat penelitian \& metode penelitian sosial. Pustaka Pelajar.

Mas' ud, A., Ismail, S. M., Huda, N., \& Kholiq, A. (2002). Dinamika pesantren dan madrasah. Kerja sama Fakultas Tarbiyah, IAIN Walisongo dengan Pustaka Pelajar, Yogyakarta.

Mastuhu. (1994). Dinamika sistem pendidikan pesantren: suatu kajian tentang unsur dan nilai sistem pendidikan pesantren. INIS.

Munawwir, A. W., \& Munawwir, Z. A. (1997). Al-Munawwir, Kamus Arab-Indonesia. Unit Pengadaan Buku-Buku Ilmiah Keagamaan, Pondok Pesantren” Al-Munawwir”.

Muttaqin, R. (2016). Kemandirian dan pemberdayaan ekonomi berbasis pesantren (studi atas peran Pondok Pesantren Al-ittifaq Kecamatan Rancabali Kabupaten Bandung terhadap kemandirian eknomi santri dan pemberdayaan ekonomi masyarakat sekitarnya). JESI (Jurnal Ekonomi Syariah Indonesia), 1(2), 65-94.

Nadzir, M. (2016). Membangun Pemberdayaan Ekonomi di Pesantren. Economica: Jurnal Ekonomi Islam, 6(1), 37-56.

Nahrawi, A. (2008). Pembaharuan Pendidikan Pesantren. Jakarta: Gama Media.

Nasrullah, M., Ismanto, K., \& Nalim, N. (2018). Economic Independence of Pesantren. HUNAFA: Jurnal Studia Islamika, 15(2), 251-272.

Noviyanti, R. (2017). Peran Ekonomi Kreatif terhadap Pengembangan Jiwa Entrepreneurship di Lingkungan Pesantren. Intaj, 1(1), 77-99. 
Nuha, U. (2016). The Role Of Pondok Pesantren In Encountering Asean Economic Community (AEC). Addin, 10(2), 103-116.

Pesantren, M. B. (2006). Revitalisasi Pesantren: Pasang Surut Peran dan Fungsi Pesantren. Majalah Bina Pesantren.

Prastyo, H. (2017). Pemberdayaan Pesantren: membangun Generasi Islami melalui Pembinaan Keterampilan Berbahasa Asing. Al-Murabbi: Jurnal Studi Kependidikan dan Keislaman, 4(1), 17-28.

Qomar, M. (2002). Pesantren: dari Transformasi Metodologi menuju Demokratisasi Institusi. Jakarta: Erlangga.

Reginald, A. R., \& Mawardi, I. (2015). Kewirausahaan Sosial Pada Pondok Pesantren Sidogiri Pasuruan. Jurnal Ekonomi Syariah Teori dan Terapan, 1(5).

Reginald, A. R., \& Mawardi, I. (2015). Kewirausahaan Sosial Pada Pondok Pesantren Sidogiri Pasuruan. Jurnal Ekonomi Syariah Teori dan Terapan, 1(5).

Rimbawan, Y. (2012). Pesantren dan Ekonomi: Kajian Pemberdayaan Ekonomi Pesantren Darul Falah Bendo Mungal Krian Sidoarjo Jawa Timur. Conference Proceedings: Annual International Conference on Islamic Studies (AICIS) XII, 5-8 November 2012, Surabaya Indonesia.

Rimbawan, Y. (2012). Pesantren dan Ekonomi: Kajian Pemberdayaan Ekonomi Pesantren Darul Falah Bendo Mungal Krian Sidoarjo Jawa Timur. digilib.uinsby.ac.id.

Rofiq, A. (2005). Pemberdayaan Pesantren: Menuju Kemandirian dan Profesionalisme Santri dengan Metode Daurah Kebudayaan. PT. LKiS Pelangi Aksara.

Sakdiyah, H. S. H. (2012). Revitalisasi entreprenuership di pondok pesantren. Al-Ihkam: Jurnal Hukum \& Pranata Sosial, 5(2), 275-290.

Santosa, S. (2011). Multiplier Efek Kampung Industri Kasongan. Jurnal Media Wisata Wahana Informasi Pariwisata, 6(1). 
Sanusi, U. (2012). Pendidikan Kemandirian di Pondok Pesantren. Jurnal Pendidikan Agama Islam-Ta'lim, 10(2), 123-139.

Siswanto, S., Armanu, T., Setiawan, M., \& Nimran, U. (2013). Entrepreneurial Motivation in Pondok Pesantren. Internatonal Journal of Business and Behavioral Sciences (IJBBS), 3(2), 42-54.

Sondakh, M. L., \& Pakasi, C. B. (2017). Analisis Multiplier Effect Agribisnis Tomat Terhadap Perekonomian Di Desa Tonsewer Selatan Kecamatan Tompaso Barat. Agri-Sosioekonomi, 13(1A), 195-202.

Suaedy, A. (Ed.). (2000). Pergulatan Pesantren dan Demokratisasi. Diterbitkan atas kerja sama LKiS dengan P3M Jakarta dan Pact-INPI Indonesia, Jakarta.

Sudjak, S., Asiyah, U., \& Prasetyo, R. A. (2018). The Role of Islamic Boarding School as Socialization Agent of Ecological Values (A Case Study in Salaf-Modern Islamic Boarding School). Wacana Jurnal Sosial dan Humaniora, 20(4).

Suwito, N. S. (2017). Model Pengembangan Ekonomi Pondok Pesantren. EDUKASI: Jurnal Penelitian Pendidikan Agama dan Keagamaan, 6(3).

Suyatman, U. (2017). Pesantren Dan Kemandirian Ekonomi Kaum Santri (Kasus Pondok Pesantren Fathiyyah Al-Idrisiyyah Tasikmalaya). AlTsaqafa: Jurnal Ilmiah Peradaban Islam, 14(2), 303-314.

Syakur, A. (2009). Optimalisasi Peran Pesantren Dalam Pengembangan Ekonomi Syari冈ah. Iqtishoduna, 4(3).

Umiarso \& Nurzazin, N. (2011). Pesantren di Tengah Arus Mutu Pendidikan Menjawab Problematika Kontemporer Manajemen Mutu Pesantren.

Wekke, I. S. (2012). Pesantren dan Pengembangan Kurikulum Kewirausahaan: Kajian Pesantren Roudahtul Khuffadz Sorong Papua Barat. Inferensi, 6(2), 205-226.

Wekke, I. S. (2016). Religious education and empowerment: study on pesantren in muslim minority West Papua. MIQOT: Jurnal Ilmu-ilmu 
Keislaman, 37(2).

Widodo, S. (2010). Pengembangan Potensi Agribisnis dalam Upaya Pemberdayaan Ekonomi Pondok Pesantren; Kajian Ekonomi dan Sosiokultural. digilib.uinsby.ac.id.

Zuhairini, D. (1992). Dkk. Sejarah Pendidikan Islam. Jakarta: Bumi Aksara.

Frechtling, D. C. (1994). Assessing the economic impacts of travel and tourism-Introduction to travel economic impact estimation. Travel, Tourism and Hospitality Research, John Wiley and Sons.

Domański, B., \& Gwosdz, K. (2010). Multiplier effects in local and regional development. Quaestiones Geographicae, 29(2), 27-37. 


\section{Shirkah Author Guidelines}

Shirkah currently offers two routes to submit manuscripts. We highly recommend to submit the articles which are made using OJS (Open Journal System). Feel free register as author soon through visiting http:// shirkah.or.id/index.php/home/user/register. The authors may directly send their manuscripts, along with their resume, to shirkahiainsurakarta@ gmail.com. Please prepare your manuscripts, using following guidelines:

1. Manuscript must be written in English. Submitted articles should not have been published or be under review for publication with another journal.

2. Manuscript's length is about $15-20$ pages, typed in one-half spaced on A4-paper size.

3. Manuscript must include an $150-200$ word abstract and keywords.

4. Manuscript must be arranged as follows: Title, Name of Author, E-mail address, Abstract, Keywords, Introduction (including method if any), Discussion, Conclusion, References.

5. Manuscript's titles not more than ten words.

6. Manuscript must be submitted in Microsoft Word or RTF.

7. Arabic words should be transliterated according to the style of International Journal of Middle Eastern Studies.

8. Manuscript references are preferably derived from the up-to-date references.

9. The author's resume should be submitted separately, consisting of at least full name, institutional address, phone number, areas of studies, and recent publications (if any).

10. Shirkab use APA Style 6th edition (2010) as reference format writing. We suggest the use of a reference manager software such as Mendeley, Zotero, and Endnote at templating the citation style. APA Style to be used is as follows: 


\section{Book with single author}

Swann, G. M. Peter. (2014). The Economics of Innovation an Introduction. Cheltenhum \& Northampton: Edward Elgar.

in-text citation: (Swann, 2014)

\section{Articles in reference books}

Alatas, S. F. (2006). Islam and the Science of Economics in Abu Rabi', I.M. The Blackwell Companion to Contemporary Islamic Thought. USA: Willey-Blackwell (pp. 587-606).

in text citation: (Alatas, 2006)

\section{E-Book}

Hackett, Rosalind (2007). "Religous Dimentions of War and Peace: Introduction.” Dalam Gerrie ter Haar dan Yoshio Tsuruoka (Ed.), Religion and Society: An Agenda for the 21st Century (h. 3-6). Retrieved from http:// brill.nl.

in text citation: (Hackett, 2006)

\section{Master's thesis, from a commercial database}

McNieI, D. S. (2006). Meaning through narrative: A personal narrative discussing growing up with an alcoholic mother (Master's thesis). Available from ProQuest Dissertations and Theses database. (UMI No. 1434728)

in text citation: (Mc Niel, 2006)

\section{Doctoral dissertation, from an institutional database}

Adams, R. J. (1973). Building a foundation for evaluation of instruction in higher education and continuing education (Doctoral dissertation). Retrieved from http://www.ohiolink.edu/etd/

in text citation: (Adams, 1973) 


\section{Doctoral dissertation, from the web}

Bruckman, A. (1997). MOOSE Crossing: Construction, community, and learning in a networked virtual world for kids (Doctoral dissertation, Massachusetts Institute of Technology). Retrieved from http:/www-static. cc.gatech.edu/--asb/thesis/

in text citation: (Bruckman, 1997)

\section{Journal article with No DOI}

Bourkhis, K., and Nabi, M. S. (2013). Islamic and conventional banks' soundness during the 2007-2008 financial crisis. Journal Metrics, 22(2), 68-77.

in-text citation: (Bourkhis \& Nabi, 2013).

\section{Journal article with DOI}

Ichwan, M. (2012). The Local Politics Of Orthodoxy: The Majelis Ulama Indonesia in the Post-New Order Banten. Journal Of Indonesian Islam, 6(1), 166-194. doi:http://dx.doi.org/10.15642/JIIS.2012.6.1.166-194

In text citation : (Ichwan, 2012)

\section{Abstract as citation}

Hasan, N. (2012). Islamist Party, Electoral Politics And Da'wah Mobilization Among Youth : The Prosperous Justice Party (PKS) in Indonesia. Journal of Indonesian Islam, 6(1), 17-47. Abstract from http:// jiis.uinsby.ac.id/index.php/jiis/article/view/97

in text citation : (Hasan, 2012)

\section{Mass media article}

Sahal, Akhmad (2014, March 2). Kiai Sahal dan Realisme Fikih.Tempo Magazine, p. 120.

in text citation : (Sahal, 2014) 


\section{Research report}

Fisher, B. S., Cullen, F. T., \& Turner, M. G. (2000). The Sexual Victimization of College Women. Research Report.

in text citation : (Fisher, Cullen, Turner, 2000)

\section{Monograph}

Routray, Bibhu Prasad (2013), National Security Decision-Making in India (RSIS Monograph No. 27). Singapura: Rajaratnam School of International Studies.

in text citation : (Routray, 2013)

\section{Proceeding article}

Sudibyakto, Hizbaron, D.R., \& Jati, R (Ed.) (2009), Proceeding International Seminar Disaster Theory, Research and Policy. International seminar held by Sekolah Pascasarjana, Universitas Gajahmada, Yogyakarta, 8-9 Desember 2009.

in text citation : (sudibyakto and Jati, 2009)

\section{Paper conference/seminar/symposium}

Janutama, Herman Sinung (2011). "Kraton dan Hubungan Antar Agama." Paper presented in Seminar Kraton dan Panatagama held by Center for the Study of Islam and Social Transformation (CISForm), Yogyakarta, 17 November.

$$
\text { in text citation :(Janutama, 2011) }
$$

\section{Online article in web}

Shiva, (2006, February). Bioethics: A Third World Issue. Native-web. Diperoleh dari http://www.nativeweb.org/ pages/legal/shiva.html 


\section{in text citation : (Shiva, 2006)}

\section{Online research report}

Kessy, S. S. A., \& Urio, F M. (2006). The contribution of microfinance institutions to poverty reduction in Tanzania (Research Report No. 06.3). Retrieved from Research on Poverty Alleviation website: http://www. repoa.or.tz /documents_storage/Publications/Reports/06.3_Kessy_and_ Urio.pcif

in text citation : (kessy and urion, 2006)

\section{Holy book}

Qur an, $2(25)$

In text citation : (Q. al-Baqarah 2:25).

\section{Encyclopaedia}

Graycar, Adam (1992). Social Welfare Policy. Dalam Mary Hawkesworth dan Maurice Kogan (Ed.), Encyclopedia of Government and Politics (Vol. 1). London: Routledge.

in text citation : (Graycar, 1992)

\section{Interview}

Sultan Hamengkubuwono X (interview, 2011, April 19)

in text citation : (Hamengkubuwono, 2011)

\section{Documentary film}

Steijlen, Fridus (2008). A Day in the Life of Indonesia [documentary film, 58 minutes]. Leiden: KITLV Press.

in text citation : (Steijlen, 2008) 
Vol. 4 No. 3, September - December 2019 